\title{
HIV risk behavior of psychiatric patients with mental illness: a sample of Brazilian patients
}

\section{Comportamento de risco para o HIV de pacientes psiquiátricos: uma amostra de pacientes brasileiros}

\author{
Mark Drew Crosland Guimarães, ${ }^{1,2}$ Karen McKinnon, ${ }^{3,4}$ Lorenza Nogueira Campos, $^{2,5}$ Ana Paula Souto Melo, ${ }^{2,6}$ \\ Milton Wainberg ${ }^{3,4}$ \\ ${ }^{1}$ Department of Preventive and Social Medicine, School of Medicine, Universidade Federal de Minas Gerais (UFMG), Belo Horizonte, MG, \\ Brazil \\ ${ }^{2}$ Research Group on Epidemiology and Health Evaluation, Universidade Federal de Minas Gerais (UFMG), Belo Horizonte, MG, Brazil \\ ${ }^{3}$ HIV Center for Clinical and Behavioral Studies, Columbia University, New York, USA \\ ${ }^{4}$ New York State Psychiatric Institute, New York, USA \\ ${ }^{5}$ State Health Department, Hospital Eduardo de Menezes, Belo Horizonte, MG, Brazil \\ ${ }^{6}$ Raul Soares Psychiatric Institute and Teaching Hospital, Fundação Hospitalar do Estado de Minas Gerais (FHEMIG), Minas Gerais State \\ Health Department, Belo Horizonte, MG, Brazil
}

\begin{abstract}
Objective: The prevalence of HIV among psychiatric patients is higher than general population rates worldwide. Many risk behaviors have been identified in studies from both developing and developed countries, though sampling limitations restrict the generalizability of their results. The objective of this study was to report findings from the first national sample of psychiatric patients about lifetime practice of unsafe sex and associated factors. Method: A national multicenter sample of adults with mental illness was randomly selected from 26 public mental health institutions throughout Brazil. Sociodemographic, sexual behavior and clinical data were obtained from person-to-person interviews and blood was collected for serology testing. Logistic regression was used for analysis. Results: The overall prevalence of lifetime unprotected sex was $80.3 \%$. Married, older, female patients, those with multiple partners and living with children or partners only and those with less severe psychiatric diagnosis more often practised unsafe sex. Discussion: Risk behavior assessment is a critical tool for clinicians to be able to determine needed HIV-related services for their clients and ensure appropriate followthrough with care and prevention. Interventions that address situational risks in psychiatric patients' lives-institutional and individual- and increase their ability to make informed decisions about their sexual health are urgently needed.
\end{abstract}

Descriptors: HIV; Mental disorders; Sexual behavior; Developing countries; Multicenter study

\begin{abstract}
Resumo
Objetivo: A prevalência do HIV em pacientes psiquiátricos é maior do que na população geral em diversos países. Diversos comportamentos de risco têm sido identificados em estudos em paises desenvolvidos e em desenvolvimento. Entretanto, limitaçôes amostrais restringem a generalização dos resultados em sua grande maioria. O objetivo deste trabalho foi apresentar resultados do primeiro estudo representativo de uma amostra nacional de pacientes psiquiátricos sobre a prática do sexo desprotegido e seus fatores associados. Método: Uma amostra representativa de pacientes adultos com transtornos mentais foi aleatoriamente selecionada de instituiçôes públicas de saúde mental no Brasil. Dados sociodemográficos, comportamentais e clínicos foram obtidos por entrevista face-a-face e sangue foi coletado para exames sorológicos. Foi utilizada regressão logística para análise estatística. Resultados: A prevalência da prática do sexo desprotegido ao longo da vida foi de 80,3\%. Pacientes casados/em união, mais velhos e do sexo feminino, aqueles com múltiplos parceiros e morando somente com filhos ou com parceiros e aqueles com condiçôes psiquiátricas menos graves praticaram o sexo desprotegido mais frequentemente. Discussão: A avaliação de comportamentos de risco é um instrumento critico para que profissionais de saúde sejam capazes de determinar as necessidades de cuidados relacionados ao HIV para seus pacientes garantindo o acesso ao tratamento e prevenção. Intervenções que abordam situaçôes de risco na vida dos pacientes psiquiátricos - institucional ou individual - e que contribuam para sua capacidade de tomar decisóes informadas sobre sua saúde sexual são urgentemente necessárias.
\end{abstract}

Descritores: HIV; Transtornos mentais; Comportamento sexual; Países em desenvolvimento; Estudo multicêntrico

\section{Introduction}

The prevalence of the Human Immunodeficiency Virus (HIV) infection among psychiatric patients in developed countries ranges from 0 to $29.0 \%$ and in developing countries from 0 to $23.8 \%$ among 24 published studies, and higher infection rates 
in this population relative to the general population are the rule. ${ }^{1}$ Most HIV studies of psychiatric patients have focused on people with severe mental illness (SMI), the term used to describe a constellation of diagnoses which includes the major psychiatric disorders such as schizophrenia, schizoaffective disorder, bipolar disorder and major depression with psychotic features. ${ }^{2}$ These disorders are characterized by persistent and chronic symptoms and pervasive impairment of function, and typically require periods of hospitalization. ${ }^{3}$

More than $50 \mathrm{HIV}$ risk behavior studies have been conducted in both developing and developed countries, though sampling limitations restrict the generalizability of their results. Current injection drug use (IDU) among people with a primary diagnosis of SMI is uncommon, but over $20.0 \%$ of psychiatric patients report a history of IDU, and most who have injected have shared needles. ${ }^{4}$ In developed countries, lifetime rates of injection range from $15.0 \%$ to $37.0 \%$, with past-year rates from $1.0 \%$ to $8.0 \%{ }^{5}$ The few studies from developing countries show that IDU varies considerably between samples and regions, with rates ranging from $0 \%{ }^{6}$ to $23.3 \%$. $^{7-9}$

Reported rates of being sexually active in the recent past are lower in developing countries than the ranges found in developed countries, where between $51.0 \%$ and $74.0 \%$ of adults with SMI report being sexually active within the past 12 months; ${ }^{4,10}$ this rate ranges from $32.0 \%$ to $65.0 \%$ in the past 3 months. ${ }^{4,11-13}$ Among people with SMI, on average, a larger proportion in the U.S. are sexually active compared to studies conducted in Australia, New Zealand, and Italy. ${ }^{4}$ In developing countries, a study in Rio de Janeiro, Brazil, found $41.8 \%$ of sexually active SMI patients in the past three months ${ }^{6}$ while in India $41.0 \%$ of psychiatric inpatients were sexually active in the past 2 years. ${ }^{9}$

Sexually active adults with SMI use condoms inconsistently. In developed countries, studies show that between $12.0 \%$ and $68.0 \%$ of SMI patients reported inconsistent use of condoms in the past 12 months, ${ }^{4,10,11,14}$ and 43.0\%-78.0\% reported having unprotected sex in the past 3 months. ${ }^{4,13}$ The only data from developing countries on condom use in the psychiatric population are from Brazil. In Rio de Janeiro, 43.9\% of outpatients had not used condoms consistently in the past three months; ${ }^{6}$ and in Minas Gerais, $68.2 \%$ of the sexually active sample of male inpatients reported never using condoms. ${ }^{15}$ Comparisons between samples are difficult given the varying time frames for behavior self-reports, the highly selective nature of the participating patients, and the differences in the psychiatric diagnosis inclusion criteria. Reliability of sexual risk behavior self-reports has been established only in the US and Brazil and only for 3- to 6-month recall periods. ${ }^{16-18}$

Research which spans the past 18 years and several countries clearly demonstrates that individuals with SMI are at risk for HIV infection through both proximal and more remote exposures by virtue of IDU and unprotected sex. HIV testing in this population, however, is not commensurate with demonstrated levels of infection and risk. ${ }^{5,19}$ Even if half of the population was not sexually active in the prior 3 to 6 months, exposure to HIV might nevertheless have occurred prior to that time, and having a reliable lifetime risk behavior assessment would be a critical tool for clinicians to be able to determine needed HIV-related services for their clients and ensure appropriate follow-through with care and prevention interventions.

This study reports findings from the first national sample of psychiatric patients' lifetime risk behavior self-reports; the lifetime prevalence of unprotected sexual risk behavior; and the associations between demographic, clinical, and contextual factors and lifetime sexual risk behavior.

\section{Method}

\section{Participants}

This national cross-sectional multicenter study was conducted in Brazil in 2006 (PESSOAS Project--HIV Seroprevalence Survey in Mental Health) among adults with mental illness under the care of public psychiatric hospitals and public mental health outpatient clinics, known as Psychosocial Care Centers (CAPS), previously described. ${ }^{20}$ Briefly, our eligibility criteria included adult (18 years old or over) inpatients or outpatients under care either at hospitals or adult CAPS who were capable of providing written informed consent, and able to answer the questionnaire described below. Patients were interviewed, and blood was collected for serology (HIV, hepatitis B and C, and syphilis). The sample size ( $\mathrm{n}=2475)$ was obtained using a two-stage sampling strategy. In the first stage, the centers within each of the five Brazilian geographical regions were randomly selected proportional to the number of beds for the hospital stratum or the number of registered patients for the CAPS stratum, leading to the selection of eleven hospitals and fifteen CAPS. The second stage was simple random probability sampling of patients from each site. ${ }^{20}$

Because we aimed to obtain a wider representation of adult patients with chronic mental illness, CAPS which exclusively treated substance use disorders as primary diagnoses were excluded from the sampling frame due to the possibility of overestimating selected risk behaviors and/or prevalence rates. Ethical approval was obtained from each treatment site, the Universidade Federal de Minas Gerais Institutional Review Board (UFMG/ETIC 125/03) and the National Ethical Review Board (CONEP 592/2006).

The patients' capacity to participate in and understand the aims of the study was evaluated through a preliminary assessment adapted from the Minimental Status Examination by trained mental health professionals (brief-MMSE). ${ }^{21} \quad$ Seven objective questions were asked relevant to orientation [4 questions], memory [2 questions] and attention [1 question]. In addition, the presence of acute psychosis or suicidality was ascertained using a qualitative assessment. A final judgment was based on the combined assessment, and those capable and eligible to participate were asked to sign a written informed consent.

\section{Exposure and event measurements}

We obtained self-reported data from face-to-face interviews conducted by experienced and trained mental health care 
professionals using a pre-tested semi-structured questionnaire. ${ }^{22}$ Sociodemographic data (e.g. age, gender, skin color, schooling, income), clinical characteristics (e.g. hospitalization history, history of sexually transmitted infections (STI), previous HIV testing, behavioral variables (e.g. sexual practices, alcohol, tobacco and illicit substance use, history of violence), and assessment of HIV/AIDS knowledge and perception of risk for HIV infection were obtained during interviews.

To assess reliability of the interview, a 5\% sample of the interviewees was randomly selected for re-interview up to seven days following the first interview. Good to excellent reliability was found for all self-report data included in the present analysis, e.g., previous psychiatric admissions (kappa $=0.94)$, psychiatric diagnoses $(\mathrm{kappa}=0.85)$, being sexually active $($ kappa $=0.76)$, history of HIV testing (kappa $=0.73)$, homelessness $($ kappa $=$ $0.72)$, HIV/STI history (kappa $=0.70)$, and recent $(<$ six months) and lifetime condom use (kappa $=0.66$ and 0.64 , respectively). ${ }^{22,23}$

Psychiatric diagnoses were obtained from medical charts and were coded according to the International Classification of Diseases (ICD-10), the standard reference for public psychiatric services in Brazil. When more than one psychiatric diagnosis was present, these were hierarchically grouped according to clinical severity as follows: (1) schizophrenia and other psychotic disorders; (2) bipolar disorder; (3) depression; (4) anxiety; (5) substance use disorder; (6) others. HIV/AIDS knowledge was assessed through ten true or false questions; good HIV/AIDS knowledge was defined as having eight or more right answers in those items while having a score of seven or less was considered poor HIV/AIDS knowledge. These statements have been used in prior studies and were derived from Brazilian population-based studies. ${ }^{24}$ Sexual behavior was assessed in two time frames, lifetime and in the past six months and included condom use, types of practices, and number of partners. ${ }^{22}$ Condom use was assessed as always, sometimes (more than $50 \%$ of the time), rarely (less than $50 \%$ of the time) and never. For the current analysis we defined unprotected sex as not always using condoms in all practices during lifetime, i.e., sometimes, rarely or never; safe sex was defined as always using condoms in all practices or never having sex.

\section{Data analysis}

Descriptive analysis was carried out and the chi-square test was performed for the analysis of categorical data. The magnitude of the associations between putative risk factors and unsafe sexual behavior was estimated by the odds ratio (OR) with $95 \%$ confidence interval $(95 \% \mathrm{CI})$. The level of significance was 0.05. The independent effect of potential exposure variables was assessed by multivariate analysis using logistic regression. All variables with p-values equal to or less than 0.20 obtained in the univariate analysis were used to start multivariate modeling. A backward deletion strategy was applied and those variables with p-values equal to or less than 0.05 remained in final model. SAS System ${ }^{\circledR}$ was used for data analysis and Paradox ${ }^{\circledR}$ Windows for database management.

\section{Results}

\section{Recruitment}

Among the 3,255 recruited patients, 492 (15.1\%) were not capable of participating according to the preliminary assessment and $2763(84.9 \%)$ were invited to participate. Among these, 2475 were interviewed $(89.6 \%)$, and 288 were non-participants (10.4\%). Reasons for non-participation were refusals $(52.0 \%)$, not being located $(19.1 \%)$, missed appointments $(8.0 \%)$, non-eligible $(3.8 \%)$, legally incapable $(1.0 \%)$, death $(0.7 \%)$, and other (15.4\%). There was no difference between participants and non-participants with regard to schooling $(\mathrm{p}=0.07)$, age $(\mathrm{p}=$ $0.593)$, gender $(p=0.276)$ or psychiatric diagnosis $(p=0.551)$. However, hospital patients had a higher participation rate as compared to CAPS patients $(\mathrm{p}<0.01)$. Eighty-one percent of the centers $(n=21)$ were public institutions while the remainder were private with partial public funding; a detailed description of the institutions was previously reported. ${ }^{25}$

\section{Descriptive characteristics}

Sixty-four percent of the participants were under treatment at CAPS while the remaining 36.0\% were under the care of psychiatric hospitals, consistent with the sampling strategy. Most participants were female $(51.6 \%)$, older than 40 years of age $(54.6 \%)$, black or mulatto $(48.5 \%)$, and $33.2 \%$ were married or in a long-term/stable unions (Table 1). Half of the sample had less than five years of schooling, $17.9 \%$ were not able to read or write, and for $35 \%$ of participants, family monthly income was lower than the Brazilian minimum wage (US\$200). Approximately $15.0 \%$ of participants were living only with either their children or partners, while $11.2 \%$ reported living completely alone and $8.3 \%$ reported living in the hospital; $18.0 \%$ had a history of homelessness.

Schizophrenia-spectrum diagnoses and bipolar disorder were the most common diagnoses (56.7\%) followed by depression $(12.9 \%)$, substance use disorder $(7.0 \%)$, and anxiety disorder (3.6\%). Other diagnoses not classified in the above categories included: epilepsy, personality disorders, dementias, and under investigation. Previous psychiatric hospitalization was reported by a large proportion of patients (58.2\%). Twenty-seven percent of participants had a history of STI, and more than one quarter had been previously tested for HIV.

A large proportion had been sexually active at some point during their lifetime $(87.7 \%)$ or during the past six months $(61.3 \%)$ with a very low proportion always using condoms: $8.3 \%$ lifetime and $16.3 \%$ past six months. Overall lifetime unprotected sex was reported by $80.3 \%, 61.0 \%$ had multiple sexual partners (>1), and $12.3 \%$ and $17.4 \%$ received or offered money for sex, respectively. High proportions of lifetime occurrences of verbal, physical or sexual violence were reported - 68.9\%, 58.0\% and $19.9 \%$, respectively, and a history of incarceration was reported by $25.7 \%$. Substance use was less common, with $25.1 \%$ reporting any use of illicit drugs and $2.9 \%$ of injected drugs. However, there was a high proportion of patients with a lifetime history of cigarette smoking $(71.5 \%)$ or alcohol use (64.4\%), while $7.9 \%$ 
Table 1 - Descriptive characteristics among the participants. PESSOAS Project, Brazil, 2006 (cont'd)

\begin{tabular}{|c|c|}
\hline \multirow[t]{2}{*}{ Characteristics } & \multirow{2}{*}{$\frac{\text { Total }}{\mathrm{n}(\%)^{\circ}}$} \\
\hline & \\
\hline \multicolumn{2}{|l|}{ SOCIODEMOGRAPHIC } \\
\hline \multicolumn{2}{|l|}{ 1. Type of recruitment center } \\
\hline Hospital & $898(36.3)$ \\
\hline CAPS & $1577(63.7)$ \\
\hline 2. Gender (Female) & $1277(51.6)$ \\
\hline 3. Age ( $\geq 40$ years old) & $1351(54.6)$ \\
\hline 4. Skin color (black/mulatto) & $1200(48.5)$ \\
\hline 5. Marital status (married or in union) & $821(33.2)$ \\
\hline 6. Know how to read/write & $2032(82.1)$ \\
\hline 7. Schooling $(<5$ years) & $1253(50.6)$ \\
\hline 8. Family income in the last month $(<1 \mathrm{MW})^{* *}$ & $827(35.2)$ \\
\hline \multicolumn{2}{|l|}{ 9. Current housing partnership } \\
\hline Living with others & $1629(65.8)$ \\
\hline Living alone with children or partners only & $359(14.5)$ \\
\hline Living in the hospitals & $206(8.3)$ \\
\hline Living alone & $278(11.2)$ \\
\hline 10. History of homelessness & $444(18.0)$ \\
\hline \multicolumn{2}{|l|}{ CLINICAL } \\
\hline 11. Previous hospitalization & $1434(58.2)$ \\
\hline \multicolumn{2}{|l|}{ 12. Psychiatric diagnosis (ICD-10) } \\
\hline Anxiety & $89(3.6)$ \\
\hline Depression & $318(12.9)$ \\
\hline Substance use & $173(7.0)$ \\
\hline Psychoses and Bipolar Disorder & $1403(56.7)$ \\
\hline Others & $492(19.9)$ \\
\hline 13. History of $\mathrm{ST} \mathrm{I}^{\star \star \star}$ & $568(23.3)$ \\
\hline 14. Previous HIV testing & $668(27.0)$ \\
\hline \multicolumn{2}{|l|}{ BEHAVIORAL } \\
\hline $\begin{array}{l}\text { 15. Age of first sexual intercourse }(<18 \text { years } \\
\text { old) }\end{array}$ & $1193(57.4)$ \\
\hline 16. Lifetime sexually active & $2172(87.8)$ \\
\hline 17. Sexually active in the past six months & $1517(61.3)$ \\
\hline 18. Always used condoms (lifetime) ${ }^{\dagger}$ & $179(8.2)$ \\
\hline 19. Always used condoms (past six months) ${ }^{\dagger}$ & $245(16.1)$ \\
\hline 20. Lifetime unprotected sex & $1970(80.3)$ \\
\hline 21. Received money for sex & $301(12.3)$ \\
\hline 22. Offered money for sex & $428(17.4)$ \\
\hline 23. Multiple sexual partners ever $(>1)$ & $1523(61.5)$ \\
\hline 24. Lifetime physical violence & $1431(58.0)$ \\
\hline 25. Lifetime sexual violence & $488(19.9)$ \\
\hline 26. Lifetime verbal violence & $1700(68.9)$ \\
\hline 27. Lifetime incarceration & $637(25.7)$ \\
\hline 28. Lifetime illicit drug use & $621(25.1)$ \\
\hline 29. Lifetime injection drug use & $72(2.9)$ \\
\hline 30. Lifetime cigarette smoking & $1762(71.5)$ \\
\hline 31. Lifetime alcohol use & $1594(64.4)$ \\
\hline 32. Sex under the influence of drugs & $192(7.9)$ \\
\hline 33. Sex under the influence of alcohol & $606(24.8)$ \\
\hline 34. Good HIVIAIDS knowledge & $1354(55.3)$ \\
\hline 35. HIV risk self perception (high/some risk) & $957(40.8)$ \\
\hline
\end{tabular}

* Number and proportion of all participants enrolled at the study in each variable category

** Minimum wage $=$ US $\$ 200$

*** Sexually transmitted infections

${ }^{\dagger}$ Among those sexually active

"t Among all participants and excluding missing values $(n=23)$.

Unprotected $=$ sometimes, rarely or never used. had had sex under the influence of drugs and $24.8 \%$ under the influence of alcohol. Finally, 55.3\% of the participants showed good HIV/AIDS knowledge and $40.8 \%$ perceived themselves as being at high or some risk for HIV/AIDS.

\section{Univariate and multivariate analysis of lifetime unprotected sex}

The overall prevalence of lifetime unprotected sex in this population was almost two times higher for women compared to men, for those over 39 years old, and for those with relatively lower education and income $(\mathrm{p}<0.05)$ - Table 2 . The odds of lifetime unprotected sex were more than seven-fold higher among those who were married or in a stable union compared to others, and five-fold higher among those living only with either children or partners, while patients currently living in the hospitals showed a lower proportion of unprotected sex as compared to those currently living in the community. Compared to patients with severe psychiatric diagnoses (Schizophrenia-spectrum diagnoses or bipolar disorder), the odds of lifetime unsafe sex were higher among patients with anxiety by four-fold, with depression by more than three-fold, and with substance use disorder by three-fold. The odds of lifetime unsafe sex were higher among those with a history of STI by almost four-fold and with a history of HIV testing by two-fold.

Several risk behavior characteristics were strongly associated with unprotected sex in the univariate analysis including sex under the influence of alcohol or drugs, receiving or offering money for sex, and lifetime history of illicit drug or injection drug use. In addition, those reporting lifetime cigarette smoking or alcohol use were more than two times as likely to practice unprotected sex. Of note is the very strong association between having had multiple sex partners and unsafe sex. Moreover, patients with a history of physical, sexual or verbal violence and those with past incarceration were also more likely to practice unsafe sex. Lastly, a lower prevalence of lifetime unsafe sex was found among those with poorer HIV/AIDS knowledge despite the increased risk of unsafe sex found when patients perceived themselves as being at high or some risk for HIV/AIDS.

After adjustment for potential confounding factors, the multivariate analysis indicated nine variables which were independently associated with lifetime unprotected sexual behavior (Table 3): women, those older than age 40, those who were married or in a stable union, a history of STI, sex under the influence of alcohol, lifetime cigarette smoking, and having multiple partners. In addition, living only with children or partners showed an increased risk, while living in hospitals showed a negative association with unsafe sex. Further, patients diagnosed with anxiety or depression showed higher lifetime unsafe sex prevalence as compared to those with more severe diagnoses (schizophrenia spectrum diagnoses and bipolar disorders).

\section{Discussion}

This is the first study of lifetime risk behaviors in a national sample of psychiatric patients in public mental health care in Brazil or elsewhere. It is also the first to demonstrate that self-reported 
Table 2 - Univariate analysis of lifetime unprotected sex*, PESSOAS Project, Brazil, 2006 (cont'd) - PART I

\begin{tabular}{|c|c|c|c|c|c|}
\hline Characteristics & Total & Unprotected sex ${ }^{\star *}$ & Odds Ratio & $(95 \% \mathrm{Cl})$ & p-value \\
\hline \multicolumn{6}{|l|}{ SOCIODEMOGRAPHIC } \\
\hline \multicolumn{6}{|l|}{ 1. Type of recruitment center } \\
\hline Hospital & 889 & $708(79.6)$ & 0.93 & $(0.76-1.15)$ & 0.509 \\
\hline CAPS & 1563 & $1262(80.7)$ & 1.00 & & \\
\hline \multicolumn{6}{|l|}{ 2. Gender } \\
\hline Female & 1263 & $1056(83.6)$ & 1.53 & $(1.26-1.88)$ & $<0.001$ \\
\hline Male & 1189 & $914(76.9)$ & 1.00 & & \\
\hline \multicolumn{6}{|l|}{ 3. Age (years old) } \\
\hline$>40$ & 1339 & $1134(84.7)$ & 1.83 & $(1.50-2.24)$ & $<0.001$ \\
\hline $18-39$ & 1113 & $836(75.1)$ & 1.00 & & \\
\hline \multicolumn{6}{|l|}{ 4. Skin color } \\
\hline White & 1262 & $1011(80.1)$ & 0.97 & $(0.79-1.18)$ & 0.766 \\
\hline Black/mulatto & 1190 & $959(80.6)$ & 1.00 & & \\
\hline \multicolumn{6}{|l|}{ 5. Marital status } \\
\hline Married or in union & 815 & $776(95.2)$ & 7.38 & $(5.26-10.37)$ & $<0.001$ \\
\hline Single, divorced or widowed & 1637 & $1194(72.9)$ & 1.00 & & \\
\hline \multicolumn{6}{|l|}{ 6. Know how to read/write } \\
\hline Yes & 2013 & $1656(82.3)$ & 1.85 & $(1.46-2.34)$ & $<0.001$ \\
\hline No & 439 & $314(71.5)$ & 1.00 & & \\
\hline \multicolumn{6}{|l|}{ 7. Schooling (years) } \\
\hline$<5$ & 1245 & $1005(80.7)$ & 1.05 & $(0.86-1.28)$ & 0.630 \\
\hline$\geq 5$ & 1207 & $965(80.0)$ & 1.00 & & \\
\hline \multicolumn{6}{|l|}{ 8. Family income in the last month } \\
\hline$\geq 1 \mathrm{MW}^{\star \star \star \star}$ & 1516 & $1275(84.1)$ & 1.75 & $(1.42-2.16)$ & $<0.001$ \\
\hline$<1 \mathrm{MW}$ & 816 & $613(75.1)$ & 1.00 & & \\
\hline \multicolumn{6}{|l|}{ 9. Current housing partnership } \\
\hline Living with others & 1614 & $1268(78.6)$ & 0.76 & $(0.54-1.06)$ & 0.102 \\
\hline Living with children or partners only & 358 & $344(96.1)$ & 5.06 & $(2.73-9.41)$ & $<0.001$ \\
\hline Living in hospitals & 202 & $127(62.9)$ & 0.35 & $(0.23-0.53)$ & $<0.001$ \\
\hline Living alone & 275 & $228(82.9)$ & 1.00 & & \\
\hline \multicolumn{6}{|l|}{ 10. Lifetime homelessness } \\
\hline Yes & 441 & $368(83.5)$ & 1.29 & $(0.98-1.69)$ & 0.070 \\
\hline No & 2011 & $1602(79.7)$ & 1.00 & & \\
\hline
\end{tabular}

${ }^{*}$ Not always using condoms in all practices during lifetime, i.e., sometimes, rarely or never.

** Prevalence of unprotected sex for each category.

*** Minimum wage $=$ US $\$ 200$.

${ }^{\dagger}$ Sexually transmitted infections.

more recent behavior, which may reflect short-term situational factors or psychiatric or psychosocial instability, lifetime behavior can more adequately offer potential causal associations between specific patient-level factors and unsafe sex behavior that confers increased risk for sexually transmitted infections, including HIV.

This study demonstrates that psychiatric patients are sexually active at rates similar to the overall adult population in Brazil (87.8-92.7\%). ${ }^{26}$ However it also indicates a high prevalence of sexual risk behavior and that specific contextual factors related to being in care for a psychiatric condition are differentially associated with lifetime risk behaviors among people receiving treatment in public psychiatric institutions in Brazil. In addition, psychiatric patients in public mental health care have higher risk behavior rates in comparison to the adult Brazilian population. Only $24.0 \%$ of among those sexually active, only $16.0 \%$ and $8.0 \%$ always used them in the last six months or ever, respectively. Recent data from a national sexual behavior study among adults in Brazil indicate higher rates of condom use $(35.1 \%$ in the last intercourse and $20.6 \%$ in all sexual encounters in the last year). ${ }^{27}$ In addition, use of psychoactive drugs was higher among our sample as compared to the national sample $\left(25.1 \%\right.$ and $8.9 \%$, respectively) ${ }^{28}$ despite the fact that the level of knowledge regarding HIV/AIDS was similar (55.3\% and $57.2 \%$, respectively). ${ }^{29}$ However, interpretation of data obtained from surveys with diverse sampling populations should be made with caution. The finding that those with poorer HIV/AIDS knowledge had a lower prevalence of lifetime unsafe sex than those with better knowledge may seem counter-intuitive, but prior research found a similar pattern for sexual risk in the 
Table 2 - Univariate analysis of lifetime unprotected sex , PESSOAS Project, Brazil, 2006 (cont'd) - PART II

\begin{tabular}{|c|c|c|c|c|c|}
\hline Characteristics & Total & Unprotected sex ${ }^{\star \star}$ & Odds Ratio & $(95 \% \mathrm{CI})$ & p-value \\
\hline \multicolumn{6}{|l|}{ CLINICAL } \\
\hline \multicolumn{6}{|l|}{$\begin{array}{l}\text { 11. Previous psychiatric } \\
\text { hospitalization }\end{array}$} \\
\hline Yes & 1417 & $1123(79.3)$ & 0.85 & $(0.70-1.05)$ & 0.125 \\
\hline No & 1025 & $838(81.8)$ & 1.00 & & \\
\hline \multicolumn{6}{|l|}{ 12. Psychiatric diagnosis } \\
\hline Anxiety & 88 & $82(93.2)$ & 4.00 & $(1.73-9.26)$ & $<0.001$ \\
\hline Depression & 317 & $292(92.1)$ & 3.42 & $(2.23-5.25)$ & $<0.001$ \\
\hline Substance use & 173 & $158(91.3)$ & 3.09 & $(1.79-5.32)$ & $<0.001$ \\
\hline Others & 484 & $363(75.0)$ & 0.88 & $(0.69-1.20)$ & 0.296 \\
\hline Psychoses and bipolar disorder & 1390 & $1075(77.3)$ & 1.00 & & \\
\hline \multicolumn{6}{|l|}{ 13. History of $\mathrm{STI}^{\dagger}$} \\
\hline Yes & 565 & $523(92.6)$ & 3.79 & $(2.72-5.29)$ & $<0.001$ \\
\hline No & 1854 & $1421(76.7)$ & 1.00 & & \\
\hline \multicolumn{6}{|l|}{ 14. Previous HIV testing } \\
\hline Yes & 665 & $586(88.1)$ & 2.16 & $(1.66-2.80)$ & $<0.001$ \\
\hline No & 1787 & $1384(77.4)$ & 1.00 & & \\
\hline \multicolumn{6}{|l|}{ BEHAVIORAL } \\
\hline \multicolumn{6}{|l|}{ 15. Age of first sex (years old) } \\
\hline$<18$ & 1186 & $1093(92.2)$ & 1.33 & $(0.98-1.80)$ & 0.066 \\
\hline$\geq 18$ & 875 & $786(89.8)$ & 1.00 & & \\
\hline \multicolumn{6}{|c|}{ 16. Sex under the influence of drugs } \\
\hline Yes & 192 & $175(91.2)$ & 2.69 & $(1.62-4.48)$ & $<0.001$ \\
\hline No & 2238 & $1774(79.3)$ & 1.00 & & \\
\hline \multicolumn{6}{|l|}{$\begin{array}{l}\text { 17. Sex under the influence of } \\
\text { alcohol }\end{array}$} \\
\hline Yes & 606 & $565(93.2)$ & 4.36 & $(3.12-6.10)$ & $<0.001$ \\
\hline No & 1822 & $1384(76.0)$ & 1.00 & & \\
\hline \multicolumn{6}{|l|}{ 18. Received money for sex } \\
\hline Yes & 299 & $277(92.6)$ & 3.46 & $(2.21-5.40)$ & $<0.001$ \\
\hline No & 2136 & $1676(78.5)$ & 1.00 & & \\
\hline \multicolumn{6}{|l|}{ 19. Offered money for sex } \\
\hline Yes & 423 & $379(89.6)$ & 2.39 & $(1.72-3.32)$ & $<0.001$ \\
\hline No & 2013 & $1576(78.3)$ & 1.00 & & \\
\hline \multicolumn{6}{|l|}{ 20. Multiple sex partners } \\
\hline$>1$ & 1518 & $1395(91.9)$ & 8.75 & $(6.94-11.02)$ & $<0.001$ \\
\hline$\leq 1$ & 797 & $450(56.5)$ & 1.00 & & \\
\hline
\end{tabular}

prior six months and also showed that knowledge alone did not predict any risk behavior. ${ }^{30}$ The investigators concluded that HIV/ AIDS information was more salient for patients who are sexually active, and that information is acquired on a need-to-know basis. In addition, increased risk of unsafe sex among patients who perceived themselves as being at high or some risk for HIV/ AIDS may demonstrate that patients accurately perceive their risk, though we cannot claim this conclusively since the temporal relationship between risk and perception was not established in our study.
In this sample, substance use disorder diagnosis did not confer significant increased risk relative to patients in treatment for psychosis or bipolar disorders. In the multivariate model in which potential confounding factors were controlled for, those with a chart diagnosis of anxiety or depression disorders had nearly a three-fold increase in the likelihood of having had unprotected sex relative to patients with psychosis or bipolar disorders. This argues for equal access to HIV-related services for psychiatric patients regardless of substance use. Our sample excluded CAPS which exclusively treated substance use disorders as primary 
Table 2 - Univariate analysis of lifetime unprotected sex*, PESSOAS Project, Brazil, 2006 (cont'd) - PART III

\begin{tabular}{|c|c|c|c|c|c|}
\hline Characteristics & Total & Unprotected sex ${ }^{\star *}$ & Odds Ratio & $(95 \% \mathrm{CI})$ & p-value \\
\hline \multicolumn{6}{|l|}{ BEHAVIORAL } \\
\hline \multicolumn{6}{|l|}{ 21. Lifetime physical violence } \\
\hline Yes & 1420 & $1177(82.9)$ & 1.45 & $(1.19-1.76)$ & $<0.001$ \\
\hline No & 1027 & $790(76.9)$ & 1.00 & & \\
\hline \multicolumn{6}{|l|}{ 22. Lifetime sexual violence } \\
\hline Yes & 484 & $423(87.4)$ & 1.90 & $(1.43-2.54)$ & $<0.001$ \\
\hline No & 1955 & $1534(78.5)$ & 1.00 & & \\
\hline \multicolumn{6}{|l|}{ 23. Lifetime verbal violence } \\
\hline Yes & 1687 & $1410(83.6)$ & 1.86 & $(1.51-2.28)$ & $<0.001$ \\
\hline No & 760 & $557(73.3)$ & 1.00 & & \\
\hline \multicolumn{6}{|l|}{ 24. HIVIAIDS knowledge } \\
\hline Poor & 1080 & $816(75.6)$ & 0.56 & $(0.46-0.69)$ & $<0.001$ \\
\hline Good & 1349 & $1141(84.6)$ & 1.00 & & \\
\hline \multicolumn{6}{|l|}{ 25. HIV risk self perception } \\
\hline High/some risk & 953 & $816(85.6)$ & 1.61 & $(1.29-2.01)$ & $<0.001$ \\
\hline None & 1377 & $1084(78.7)$ & 1.00 & & \\
\hline \multicolumn{6}{|l|}{ 26. History of incarceration } \\
\hline Yes & 631 & $546(86.5)$ & 1.79 & $(1.39-2.31)$ & $<0.001$ \\
\hline No & 1821 & $1424(78.2)$ & 1.00 & & \\
\hline \multicolumn{6}{|l|}{ 27. Lifetime illicit drug use } \\
\hline Yes & 616 & $546(88.6)$ & 2.25 & $(1.72-2.96)$ & $<0.001$ \\
\hline No & 1836 & $1424(77.6)$ & 1.00 & & \\
\hline \multicolumn{6}{|c|}{ 28. Lifetime injection drug use } \\
\hline Yes & 70 & $66(94.3)$ & 4.12 & $(1.49-11.36)$ & 0.003 \\
\hline No & 2367 & $1894(80.0)$ & 1.00 & & \\
\hline \multicolumn{6}{|l|}{ 29. Lifetime cigarette smoking } \\
\hline Yes & 1748 & $1468(84.0)$ & 2.07 & $(1.68-2.55)$ & $<0.001$ \\
\hline No & 693 & $497(71.7)$ & 1.00 & & \\
\hline \multicolumn{6}{|l|}{ 30. Lifetime alcohol use } \\
\hline Yes & 1583 & $1347(85.1)$ & 2.25 & $(1.84-2.76)$ & $<0.001$ \\
\hline No & 869 & $623(71.7)$ & 1.00 & & \\
\hline
\end{tabular}

*Not always using condoms in all practices during lifetime, i.e., sometimes, rarely or never.

** Prevalence of unprotected sex for each category.

*** Minimum wage $=$ US $\$ 200$.

${ }^{\dagger}$ Sexually transmitted infections.

diagnoses, which may have underestimated its effect on lifetime sexual behavior. In addition, we relied on chart diagnoses rather than obtaining research diagnoses at the time of the risk behavior interview. It should be noted, however, that many seminal studies among psychiatric patients also used chart diagnoses ${ }^{31}$ and that most studies in the literature are highly selective with regard to psychiatric diagnoses, i.e., SMI, whereas the present study represents all diagnoses addressed in the public psychiatric treatment system.

Sociodemographic and substance use patterns of association to lifetime sex risk were not dissimilar to those found in other populations studied in the AIDS epidemic. Patients over the age of 40 were one-and-a-half times as likely as those under 40 to have had unprotected sex, which is expected given the larger number of sex occasions and opportunities older people have compared to younger people. Women showed nearly a two-fold increased likelihood of having had unprotected sex compared to men. In addition, being married or in a stable union conferred nearly a nine-fold increase in the likelihood of having had unprotected sex compared to those currently single, divorced, or widowed. We did not assess whether monogamy was an expectation in these relationships nor if participants were aware of their partners' history of HIV risk behaviors (e.g., sexual risk or IDU) or HIV testing. Monogamy increases vulnerability to HIV when the sexual partner is risky, as some studies in Brazil and elsewhere with other populations have demonstrated: married/monogamous women may be at increased risk. $^{32,33}$ Sex under the influence of alcohol had more than a two-fold increase in the likelihood of having had unprotected sex, and lifetime cigarette smoking conferred more than one-and-a-half times the likelihood of having had unprotected sex. Rather than suggesting a causal relationship, this finding appears to provide evidence of an underlying tendency toward sensation-seeking, risk-taking, or impulsivity that leads people both to use substances and to have riskier sex first posited by Leigh and Stall. ${ }^{34}$ 
Table 3 - Multivariate logistic analysis of lifetime unprotected sex $^{\star}$, PESSOAS Project, 2006

\begin{tabular}{|c|c|c|}
\hline Characteristics & OR & $(95 \% \mathrm{CI})$ \\
\hline \multicolumn{3}{|l|}{ Gender } \\
\hline Female & 1.78 & $(1.34-2.37)^{\star \star}$ \\
\hline Male & 1.00 & \\
\hline \multicolumn{3}{|l|}{ Age (years old) } \\
\hline$>40$ & 1.62 & $(1.22-2.14)^{\star \star}$ \\
\hline $18-39$ & 1.00 & \\
\hline \multicolumn{3}{|l|}{ Marital status } \\
\hline Married or in union & 8.55 & $(5.77-12.7)^{\star \star}$ \\
\hline Single, divorced or widowed & 1.00 & \\
\hline \multicolumn{3}{|l|}{ History of STI } \\
\hline Yes & 2.04 & $(1.39-3.01)^{\star \star}$ \\
\hline No & 1.00 & \\
\hline \multicolumn{3}{|l|}{ Sex under the influence of alcohol } \\
\hline Yes & 2.34 & $(1.58-3.47)^{\star *}$ \\
\hline No & 1.00 & \\
\hline \multicolumn{3}{|l|}{ Lifetime cigarette smoking } \\
\hline Yes & 1.64 & $(1.23-2.19)^{\star *}$ \\
\hline No & 1.00 & \\
\hline \multicolumn{3}{|l|}{ Current housing partnership } \\
\hline Living with others & 0.70 & $(0.46-1.07)$ \\
\hline Living with children or partners only & 2.72 & $(1.35-5.48)^{\star \star \star}$ \\
\hline Living in hospitals & 0.54 & $(0.32-0.94)^{\star \star *}$ \\
\hline Living alone & 1.00 & \\
\hline \multicolumn{3}{|l|}{ Number of sexual partners ever } \\
\hline$>1$ & 10.58 & $(7.87-14.23)^{\star \star}$ \\
\hline$\leq 1$ & 1.00 & \\
\hline \multicolumn{3}{|l|}{ Psychiatric diagnosis } \\
\hline Anxiety & 2.82 & $(1.04-7.66)^{\star \star \star}$ \\
\hline Depression & 2.04 & $(1.22-3.40)^{\star \star \star}$ \\
\hline Substance use & 1.07 & $(0.57-2.00)$ \\
\hline Others & 0.97 & $(0.70-1.34)$ \\
\hline Psychoses and bipolar disorder & 1.00 & \\
\hline
\end{tabular}

* Not always using condoms in all practices during lifetime; ${ }^{* \star} p$-value $<0.001 ;{ }^{\star \star \star} p$-value $<0.05$.

One significant contextual factor that may be specific to this population which has fewer options for independent living is the finding that those patients currently living only with either children or partners had nearly a three-fold increased risk of unprotected sex compared to those living alone, whereas patients currently living in the hospital had a significantly reduced risk of lifetime unsafe sex. Prior studies of people with SMI who are homeless suggested that a lack of privacy might contribute to unsafe sexual encounters since planning to use condoms and taking the time to obtain and use them would be difficult for those living in parks or on the streets. ${ }^{35}$ This study is the first to examine the relationship between sexual risk-taking and the living arrangements of those with SMI who are not undomiciled and points toward the need for future research regarding the effects of privacy and care-taking in terms of how people prioritize their sexual safety.

The public mental health system in Brazil treats a wide range of conditions such as dementia and cognitive impairment caused by malnutrition as well as SMI and the affective disorders. To the extent that other countries and localities have similarly broad treatment mandates, this study provides striking evidence from a national sample of the enormous risks people with psychiatric illness have engaged in over their lifetimes, with implications for needed testing, treatment, and prevention interventions and services for enhancing awareness of these risks among patients, their families, and providers and decision-makers who comprise the mental health care system.

Most HIV-related research about psychiatric populations has focused on those with SMI. This study shows that this population does engage in high rates of lifetime risk behaviors but that those with anxiety disorders severe enough to warrant psychiatric hospitalization or outpatient care have even higher rates and need programming specific to their psychiatric and living conditions. Severe anxiety disorders can affect awareness, attitudes, and intentions, all of which have been shown to impinge upon risk behavior change. Even though a limitation of this study is that diagnosis was obtained from chart review, focusing on these aspects of the disorder may be especially important in future intervention development and research that build upon existing interventions and processes ${ }^{36}$ that allow for a greater understanding of the contexts of psychiatric partners' lives and increase their ability to make informed decisions about their sexual health.

\section{Acknowledgements}

Financing of this project was provided by The Brazilian National STD/ AIDS Program, Ministry of Health (Financial Support: UNESCO/DSTAids 914/BRA/1101 - Project 086/05). Dr. Guimarães was granted a Visiting Scholar Fellowship at Columbia University, New York, USA, from CAPES (Coordenação de Aperfeiçoamento de Pessoal de Nível Superior; Brazilian Higher Education Staff Development Agency, Ministry of Education) during the preparation of this manuscript. 
Disclosures

\begin{tabular}{|c|c|c|c|c|c|c|c|}
\hline $\begin{array}{l}\text { Writing group } \\
\text { member }\end{array}$ & Employment & $\begin{array}{l}\text { Research } \\
\text { grant }^{1}\end{array}$ & $\begin{array}{l}\text { Other research grant } \\
\text { or medical continuous } \\
\text { education }^{2}\end{array}$ & $\begin{array}{l}\text { Speaker's } \\
\text { honoraria }\end{array}$ & $\begin{array}{l}\text { Ownership } \\
\text { interest }\end{array}$ & $\begin{array}{c}\text { Consultant/ } \\
\text { Advisory } \\
\text { board }\end{array}$ & Other ${ }^{3}$ \\
\hline $\begin{array}{l}\text { Mark Drew Crosland } \\
\text { Guimarães }\end{array}$ & UFMG & - & - & - & - & - & - \\
\hline Karen McKinnon & $\begin{array}{c}\text { NY State } \\
\text { Psychiatric } \\
\text { Institute/HIV } \\
\text { Center }\end{array}$ & - & - & - & - & - & - \\
\hline $\begin{array}{l}\text { Lorenza Nogueira } \\
\text { Campos }\end{array}$ & $\begin{array}{l}\text { Hospital } \\
\text { Eduardo de } \\
\text { Menezes/ } \\
\text { FHEMIG }\end{array}$ & - & - & - & - & - & - \\
\hline $\begin{array}{l}\text { Ana Paula Souto } \\
\text { Melo }\end{array}$ & $\begin{array}{l}\text { Instituto Raul } \\
\text { Soares/ } \\
\text { FHEMIG }\end{array}$ & - & - & - & - & - & - \\
\hline Milton Wainberg & $\begin{array}{c}\text { NY State } \\
\text { Psychiatric } \\
\text { Institute/HIV } \\
\text { Center }\end{array}$ & - & - & - & - & - & - \\
\hline
\end{tabular}

* Modest

** Significant

*** Significant. Amounts given to the author's institution or to a colleague for research in which the author has participation, not directly to the author.

Note: UFMG = Universidade federal de Minas Gerais; FHEMIG = Fundação Hospitalar do Estado de Minas Gerais.

For more information, see Instructions for Authors.

References

1. Campos LN, Guimarães MD, Carmo RA, Melo AP, Oliveira HN, Elkington $\mathrm{K}, \mathrm{McKinnon} \mathrm{K}$. HIV, syphilis and hepatitis B and C prevalence among patients with mental illness: a review of the literature. Cad Saude Publica. 2008;24(Suppl 4):S607-20.

2. Schimnar AP, Rothbard AB, Kanter R, Jung YS. An empirical literature review of definitions of severe and persistent mental illness. Am J Psychiatry. 1990;147(12):1602-8.

3. Rosenberg SD, Trumbetta SL, Mueser KT, Goodman LA, Osher FC, Vidaver RM, Metzger DS. Determinants of risk behavior for human immunodeficiency virus/acquired immunodeficiency syndrome in people with severe mental illness. Compr Psychiatry. 2001;42(4):263-71.

4. Meade CS, Sikkema KJ. HIV risk behavior among adults with severe mental illness: a systematic review. Clin Psychol Rev. 2005;25(4):433-57.

5. Meade CS, Sikkema KJ. Voluntary HIV testing among adults with severe mental illness: frequency and associated factors. AIDS Behav. 2005;9(4):465-73.

6. Wainberg ML, McKinnon K, Elkington KS, Mattos PE, Gruber Mann C, De Souza Pinto D, Otto-Salaj L, Cournos F, PRISSMA. HIV risk behaviors among outpatients with severe mental illness in Rio de Janeiro, Brazil. World Psychiatry. 2008;7(3):166-72.

7. De Souza MM, Barbosa MA, Borges AM, Daher RR, Martins RM, Cardoso DD. Seroprevalence of hepatitis B virus infection in patients with mental problems. Rev Bras Psiquiatr. 2004;26(1):34-7.

8. Chandra PS, Carey MP, Carey KB, Prasada Rao PS, Jairam KR, Thomas T. HIV risk behaviour among psychiatric inpatients: results from a hospital-wide screening study in southern India. Int J STD AIDS. 2003;14(8):532-8.

9. Chopra MP, Eranti SS, Chandra PS. HIV-related risk behaviors among psychiatric inpatients in India. Psychiatr Serv. 1998;49(6):823-5.

10. Tucker JS, Kanouse DE, Miu A, Koegel P, Sullivan G. HIV risk behavior and their correlates among HIV-positive adults with serious mental illness. AIDS Behav. 2003;7(1):29-40.

11. Meade CS, Sikkema KJ. Psychiatric and psychosocial correlates of sexual risk behavior among adults with severe mental illness. Community Ment Health J. 2007;43(2):153-69.

12. Meade CS. Sexual risk behavior among persons dually diagnosed with severe mental illness and substance use disorder. J Subst Abuse Treat. 2006;30(2):147-57.
13. Devieux JG, Malow R, Lerner BG, Dyer JG, Baptista L, Lucenko B, Kalichman S. Triple jeopardy for HIV: substance using severely mentally ill adults. J Prev Interv Community. 2007;33(1-2):5-18.

14. Dausey DJ, Desai RA. Psychiatric comorbidity and the prevalence of HIV infection in a sample of patients in treatment for substance abuse. J Nerv Ment Dis. 2003;191(1):10-7.

15. Almeida RC, Pedroso ER. Vulnerabilidade e exposição a marcadores sorológicos dos vírus da imunodeficiência humana, hepatites $\mathrm{B}$ e $\mathrm{C}$, vírus linfotrópico de células $T$ humanas e síflis em pacientes psiquiátricos internados em hospital público. Rev Assoc Méd Minas Gerais. 2004;14(4):244-50.

16. McKinnon K, Cournos F, Meyer-Bahlburg H, Guido JR, Caraballo LR, Margoshes ES, Herman R, Gruen RS, Exner TM. Reliability of sexual risk behavior interviews with psychiatric patients. Am J Psychiatry. 1993;150(6):972-4.

17. Pinto D, Veloso Filho CL, Wainberg ML, Mattos PE, Meyer Bahlburg HF. Escala de avaliação de comportamento sexual de risco para adultos (SERBAS): Tradução e adaptação transcultural para o português brasileiro (Sexual Risk Behavior Assessment Schedule for Adults (SERBAS). Rev Psiquiatr Rio Grande do Sul. 2007;29(2):205-11.

18. Sohler N, Colson PW, Meyer-Bahlburg HF, Susser E. Reliability of self-reports about sexual risk behavior for HIV among homeless men with severe mental illness. Psychiatr Serv. 2000;51(6):814-6.

19. Walkup J, McAlpine DD, Olfson M, Boyer C, Hansell S. Recent HIV testing among general hospital inpatients with schizophrenia: findings from four New York City sites. Psychiatr Q. 2000;71(2):177-93.

20. Guimarães MD, Campos LN, Melo AP, Carmo RA, Machado CJ, Acurcio FA, PESSOAS Project Network Group. Prevalence of HIV, syphilis, hepatitis $\mathrm{B}$ and $\mathrm{C}$ among adults with chronic mental illness: a multicenter study in Brazil. Braz J Psychiatr. 2009;31(1):43-7.

21. Folstein MF, Folstein SE, Mchugh PR. "Mini-mental state": a practical method for grading the cognitive state of patients for the clinician. J Psychiatr Res. 1975;12(3):189-98.

22. Guimarães MD, Oliveira HN, Campos LN, Santos CA, Gomes CE, Oliveira SB, Freitas MI, Acúrcio Fde A, Machado CJ. Reliability and validity of a questionnaire on vulnerability to sexually transmitted infections among adults with chronic mental illness - PESSOAS Project. Braz J Psychiatr. 2008;30(1):55-9. 
23. Oliveira HN, Machado CJ, Campos LN, Acurcio FA, Guimarães MD. Avaliação da confiabilidade de entrevista aplicada a indivíduos com transtornos mentais: Projeto PESSOAS. Rev Med Minas Gerais. 2008;18(4)Suppl 4:S40-5.

24. Brazil, Ministry of Health. National Coordination for STDs and AIDS. (2005). Positive response: Experiences of the Brazilian AIDS program. Braslia, Brazil: Ministry of Health of Brazil. [cited 2006 July 23]. Available from:http://www.aids.gov.br/final/biblioteca/resposta/resposta_2005. pdf.

25. Melo APS, Acurcio FA, Cherchiglia ML, Veloso CCG, Guimarães MDC Evaluation of mental health services: care and prevention of sexually transmitted diseases within PESSOAS(*) Project context. Rev Med Minas Gerais. 2007;17(1/2 Suppl 4): S240-8.

26. Barbosa RM, Koyama MA; Grupo de Estudos em População, Sexualidade e Aids. Sexual behavior and practices among men and women, Brazil 1998 and 2005. Rev Saude Publica. 2008;42(Supl 1):21-33.

27. Brazil, Ministry of Health. Pesquisa sobre Comportamento, Atitudes e Práticas Relacionadas às DST e Aids na População Brasileira. 2009. [cited 2006 July 23]. Available from:http://www.aids.gov.br/data/Pages/LUMISE7 7B47C8ITEMIDE56B57FF739940039DB3112DF74DE47FPTBRIE. htm on July 24, 2009.

28. Bastos FI, Bertoni N, Hacker MA; Grupo de Estudos em População, Sexualidade e Aids. Drug and alcohol use: main findings of a national survey, Brazil 2005. Rev Saude Publica. 2008;42(Supl 1):109-17.

29. Ferreira MP. Knowledge and risk perception on HIV/AIDS by Brazilian population, 1998 and 2005. Rev Saude Publica. 2008;42(Supl 1):65-71.

30. McKinnon K, Cournos F, Sugden R, Guido JR, Herman R. The relative contributions of psychiatric symptoms and AIDS knowledge to HIV risk behaviors among people with severe mental illness. J Clin Psychiatry. 1996;57(11):506-13.

31. Kelly RH, Danielson BH, Zatzick DF, Haan MN, Anders TF, Gilbert WM, Burt VK. Chart-recorded psychiatric diagnoses in women giving Birth in California in 1992. Am J Psychiatry. 1999;156(6):955-7.

32. Bastos FI, Szwarcwald, CL. AIDS e pauperização: principais conceitos e evidências empíricas. Cad Saude Publica. 2000;16(Suppl 1):S65-S76.

33. Gangakhedkar RR, Bentley ME, Divekar AD, Gadkari D, Mehendale SM, Shepherd ME, Bollinger RC, Quinn TC. HIV infection in married monogamous women in India. JAMA. 1997;278(23):2090-2.

34. Leigh BC, Stall R. Substance use and risky sexual behavior for exposure to HIV. Issues in methodology, interpretation, and prevention. Am Psychol. 1993;48(10):1035-45.

35. Susser E, Valencia E, Berkman A, Sohler N, Conover S, Torres J, Betne P, Felix A, Miller S. Human immunodeficiency virus sexual risk reduction in homeless men with mental illness. Arch Gen Psychiatry. 1998;55(3):266-72.

36. Wainberg ML, McKinnon K, Mattos PE, Pinto D, Mann CG, de Oliveira CS, de Oliveira SB, Remien RH, Elkington KS, Cournos F; PRISSMA Project. A model for adapting evidence-based behavioral interventions to a new culture: HIV prevention for psychiatric patients in Rio de Janeiro, Brazil. AIDS Behav. 2007;11(6):872-83. 